\title{
躯体蓄熱冷房利用における室内湿度の上昇と改善手法の効果 ASCENT OF INDOOR HUMIDITY BY THERMAL STORAGE IN BUILDING MASS FOR COOLING AND THE EFFECT OF COUNTERMEASURES
}

三浦 克弘*, 相楽 典 泰**

\section{Katsuhiro MIURA and Noriyasu SAGARA}

\begin{abstract}
Thermal storage in building mass for cooling, which stores thermal energy in building thermal mass, has been reported to bring changes in indoor thermal environment such as the improvement of radiative environment and the ascent of humidity. The field measurement in a building in Tokyo showed that the tendency of the humidity ascent. Several cases of simulation are conducted to study the effect of the storage hours on the degree of the ascent. The study shows that the more the humidity ascent is, the longer the storage hours are. Countermeasures are necessary to keep good thermal environment and to meet the legal regulation in Japan. The effect of two measures is compared: 1. decrease of the minimum air flow rate of variable air volume system, 2. independent treatment of outdoor air. The former might bring the humidity ascent when the indoor thermal load is small. Control parameters of AHU for outdoor air should be set appropriately for the latter.
\end{abstract}

Keywords : thermal storage in building mass, indoor humidity, thermal comfort 躯体蓄熱, 室内湿度, 熱的快適性

1. はじめに

近年は地球温暖化問題が盛んに取り上げられている。空調設備 の分野もその例外ではなく、消費エネルギーの中で大きな割合を 占める電力では発電量の平準化が課題となっている。電力平準化 の手法としては水や水を利用した熱源における蓄熱が用いられる 機会が増えてきているが、初期費用や設備スペースが増えるため 適用件数が大幅に増えているとは言えない状況である。躯体蓄熱 は建築躯体の熱容量を利用して空調負荷の夜間移行を実現するも ので、空調立ち上がり時に生じる蓄熱負荷を空調開始前に処理す ると共に建築部材に積極的に蓄熱することで昼間の空調負荷を削 減する手法である。躯体蓄熱は設備コストを安価に押さえる蓄熱 方式として適用件数も増えており、総合建設業や大学を中心とし て研究が盛んに行われてきた。

躯体蓄熱は建築躯体の熱容量を利用するため顕熱成分の蓄熱を 行う。そのため、室空調時の空調機処理熱量顕熱成分を減少させ

表 1 EN ビル建築概要

\begin{tabular}{|c|c|c|c|}
\hline 建築場所 & 東京都江東区 & 建築面積 & $1,377 \mathrm{~m}^{2}$ \\
\hline 竣 & 2001年3月 & 延床面積 & $10,561 \mathrm{~m}^{2}$ \\
\hline 建物用途 & 事務所·店舗 & 構 & 鉄骨鉄筋コンクリート造 \\
\hline 階 & 地上8 階、塔屋1 階 & 最高高さ & $36.2 \mathrm{~m}$ \\
\hline 敷地面積 & $2,622 \mathrm{~m}^{2}$ & スラブ仕様 & $\begin{array}{r}\text { デッキプレート部平均スラ } \\
\text { ブ厚120mm, フリーアクセスフ } \\
\text { ロア空間高さ100mm, タイル } \\
\text { カーペット厚 } 7 \mathrm{~mm}\end{array}$ \\
\hline
\end{tabular}

ることになり、室内環境にも変化をもたらす。冷房利用時の室内 環境の変化としては放射環境の向上 ${ }^{1)}$ と共に、室内湿度の上昇 ${ }^{2)}$ が報告されている。但し、躯体蓄熱冷房利用を行う建物全てで湿 度の上昇が報告されているわけではなく、躯体蓄熱による室内湿 度の上昇に関する解析は十分に行われていない状態である。

本論文では躯体蓄熱を行う建物で実測を行い室内湿度の違いを 把握する。ついで、湿度上昇をもたらす原因を空調システムの空 気調和プロセスの観点からシミュレーションを用いて解析を行 い、湿度上昇への対応策を検討する。

\section{2. 実建物における室内湿度の比較}

2. 1 建物と空調方式

表 1 に実態調查を行った建物（以下 E N ビル）の概要を示す。建 物の竣工は 2001 年 4 月である。建物は基準階面積約 $1,400 \mathrm{~m}^{2}$ の 8 階建てのオフィス（一部店舗）で、建築断面と空の仕様を表 2 に

表 2 建築断面と空の仕様

\begin{tabular}{rrr}
\hline 部位 & 材料 & 厚み $(\mathrm{mm})$ \\
\hline 外壁 & タイル & 15 \\
& ALC & 150 \\
\hline 床 & デッキプレート(普通コンクリート) & 120 (平均厚み) \\
\hline 天井 & 石膏ボード十岩綿吸音板 & 12 \\
\hline 梁 & & 鋼 \\
& 表面吹付け岩綿(両面) & $6 \sim 14$ \\
& エアフローウインドウ & 30 \\
\hline 空 & 熱線反射ガラス & 10 \\
& 普通ガラス & 10 \\
\hline
\end{tabular}

* 鹿島建設(株技術研究所 上席研究員 ·工修 (京都大学大学院工学研究科都市環境工学専攻 博士課程)

** 北九州市立大学国際環境工学部建築デザイン学科 教授・博士 (工学)
Chief Research Engineer, Kajima Technical Research Institute, M. Eng.

(Graduate Student, Department of Urban and Environment Engineering, Graduate School of Engineering, Kyoto University)

Prof., Department of Architecture, Faculty of Environmental Engineering, The University of Kitakyushu, Dr. Eng. 
表 3 E N ビル空調設備仕様概要

\begin{tabular}{|c|c|c|c|}
\hline 室外機 & 単位 & \multicolumn{2}{|c|}{ 空冷形 } \\
\hline & 馬力 & 14 & 8 \\
\hline 親/子 & & 親機 & 子機 \\
\hline 冷房能力 & $\mathrm{kW}$ & 40 & 20 \\
\hline 圧縮機電動機出力 & $\mathrm{kW}$ & $1.5+3+6=10.5(3$ 台 $)$ & 6 \\
\hline 圧縮機容量制御 & & 16段階制御 & オンオフ制御 \\
\hline ファン定格風量 & $\mathrm{m} 3 / \mathrm{h}$ & 18600 & 9300 \\
\hline ファン電動機出力 & $\mathrm{kW}$ & $0.2+0.2=0.4$ & 0.2 \\
\hline ファン容量制御 & & 16段階制御 & オンオフ制御 \\
\hline 冷媒 & & \multicolumn{2}{|c|}{$\mathrm{R} 22$} \\
\hline 室内機 & 単位 & \multicolumn{2}{|c|}{ ビルトインオールダクト形 } \\
\hline 冷房能力 & $\mathrm{kW}$ & 5.6 & 7.1 \\
\hline 定格風量 & $\mathrm{m} 3 / \mathrm{h}$ & 急: 720, 強: 630 , 弱:540 & 強: 960 ，弱: 780 \\
\hline ファン電動機出力 & $\mathrm{kW}$ & \multicolumn{2}{|c|}{0.05} \\
\hline 台数 & 台 & \multicolumn{2}{|c|}{10} \\
\hline 永蓄熱ユニット & 単位 & \multicolumn{2}{|c|}{ 直膨形アイスオンコイル形 } \\
\hline 最大蓄熱量 & $\mathrm{MJ}$ & \multicolumn{2}{|c|}{780} \\
\hline 水張量 & $\mathrm{kg}$ & \multicolumn{2}{|c|}{2569} \\
\hline IPF & $\%$ & \multicolumn{2}{|c|}{68} \\
\hline
\end{tabular}

示す。基準階の床はデッキプレートを用いたコンクリートで平均 スラブ厚 $120 \mathrm{~mm}$ である。屋上階を除く基準階の空調設備は、イン テリアゾーンには氷蓄熱ビル用マルチ（ピークシフト型）と躯体 蓄熱の併用方式を、ペリメーターゾーンは非蓄熱ビル用マルチ方 式であった。図 1 に基準階平面図と空調系統を示す。インテリア ゾーンは平面的に 2 系統に分かれており、No. 1 系統では 12 台、No.2 系統に 8 台の室内機が設置されていた。測定を行った 7 階インテ リア系統空調設備の仕様を表 3 に示す。空調設備の運転は平日の 蓄熱時間帯 (22 時〜翌朝 8 時) に先ずビル用マルチの氷蓄熱を行い、 3 時以降に躯体蓄熱を行っていた。躯体蓄熱方式は室内機の最大 風量で天井裏空間内の上階スラブに垂直に空気を吹き付ける空気 吹付方式を用いていた。蓄熱時に天井裏空間で空気を循環させる ため室内機レタン口は天井裏に設置されており、室空調時には天 井板のスリットを通して室内に吹き出した空調空気を天井裏に導 いていた。外気は室空調時のみに還気と共に室内機のレタンロに 送風機を用いて供給しており、外調機は設置していなかった。ビ ル用マルチ室内機の制御は躯体蓄熱時には吹出空気温度を $12{ }^{\circ} \mathrm{C} て ゙$ 制御し、室空調時には室温センサーを用いて設定值による室温制 御を行った。 EN ビルでは室温設定值と風量の設定には制限は設け てられておらず、居住者が任意に設定していた。

\section{2 測定項目と測定点}

室内温湿度測定用の温度センサーと湿度センサーはビル用マル チの温度センサー近傍の壁面 $(\mathrm{FL}+1.5 \mathrm{~m})$ に設置し、空調設備の計装 に用いる温度センサーのカバーを取り付けた。温度センサーは熱 電対、湿度センサーは抵抗式の高分子型相対湿度計を用いた。図 1 に示す室内機では吹出空気温度を測定した。外界条件は屋上で 直達日射が当たらない外階段の踊り場の下で気温を測定した。測 定間隔は 5 分であった。外気湿度は東京管区気象台の観測值 ( 1 時 間間隔）を用いた。東京管区気象台は測定を行った建物から約 $3.9 \mathrm{~km}$ 離れていた。

\section{3 解析期間と解析結果}

2001 年 7 月から 8 月にかけて外気温度と室内温湿度の測定を行 い、躯体蓄熱の有無により生じる平日の室内湿度環境の違いを比 較した。解析対象としたのは期間 S（躯体蓄熱平日 2 時間）は2001

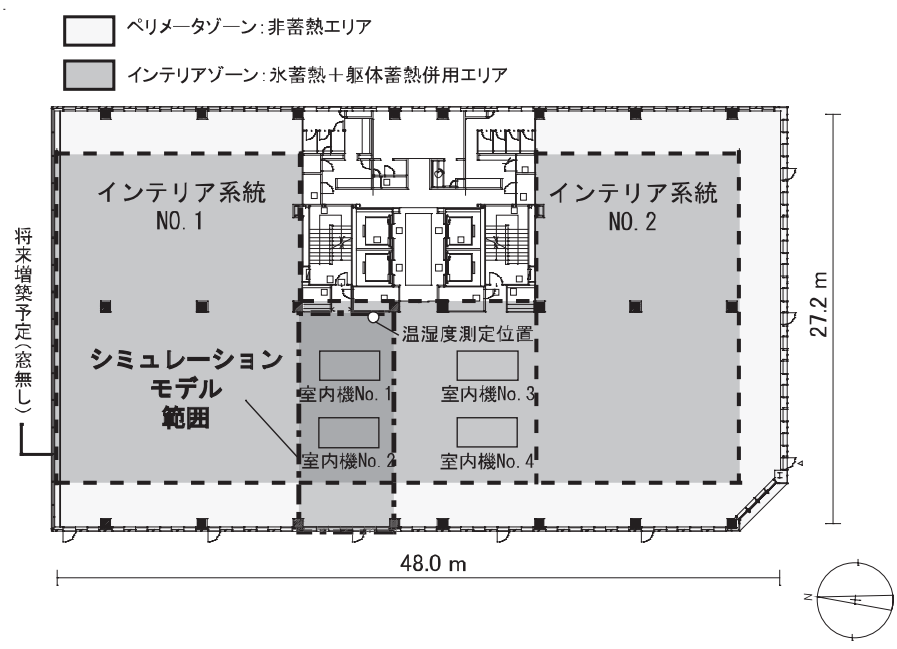

図 1 基準階平面図と空調系統

年 8 月 27 日 $($ 月) 〜 月 31 日（金)、期間 $N$ (躯体蓄熱なし）は 2001 年 7 月 30 日 (月) 〜 月 3 日 (金)である。図 2 にそれぞれの測定 期間の外気温湿度を示す。東京管区気象台で測定した気温と平年 值を比較すると 2001 年 8 月の平均気温は $26.4^{\circ} \mathrm{C}$ で平年值 $27.1^{\circ} \mathrm{C}$ 3)に比べて $0.7{ }^{\circ} \mathrm{C}$ 低かった。また、測定期間中に屋上で測定した外 気温度平均值と東京管区気象台で測定した外気絶対湿度平均值は 期間 $\mathrm{S}$ は $27.3^{\circ} \mathrm{C} と 0.0157 \mathrm{~kg} / \mathrm{kg}[\mathrm{DA}]$ 、期間 $\mathrm{N}$ は $29.7^{\circ} \mathrm{C}$ と $0.0164 \mathrm{~kg} /$

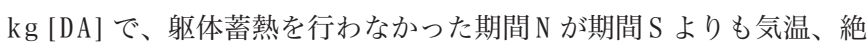
対湿度共に高かった。

上述の期間から 8 月 28 日 (期間 S ）と8月 1 日 (期間 N) を選び外 気温湿度と室内温湿度の変動を図 3 に示す。屋上で測定した外気 温度はいずれの日も $35^{\circ} \mathrm{C}$ 超えていた。 8 月 28 日では躯体蓄熱を 行う朝 6 時から 8 時にかけて躯体蓄熱を行ったため室温と室絶対

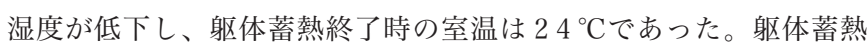
を行わなかった 8 月 1 日は予冷開始となる 8 時に吹出温度が低下 をはじめて室温と室絶対湿度が徐々に低下し 9 時以降はほぼ一定 となった。

図 4 に室内機No.1 から No. 4 の 4 台の室内機の吹出空気温度変化 を示す。(a) に示す 8 月 28 日（期間 S ）の温度変化を見ると 6 時か ら 8 時の躯体蓄熱時間は各室内機の吹出温度に変動が見られるが $15{ }^{\circ} \mathrm{C}$ を回っていた時間がほとんどであった。8 時には 4 台の室 内機は室温が低下したため送風状態で予冷運転を始めた。9 時前 に 4 台とも冷房を開始するが 11 時には再度送風状態となり、11 時 以降 15 時までは室内機 No. 2 のみが吹出温度を上下させながら冷 房を行っていた。一方、(b) の 8 月 1 日（期間 N) では 8 時の予冷開 始と共に全ての室内機の吹出温度が低下するが 9 時以降は室内機 No. 2 は送風状態となり、他の 3 台で 15 時までは安定した吹出温度 で冷房していた。

図 5 には各解析期間において室空調時間であった 9 時から 22 時 に 5 分間隔で測定した温湿度測定值 785 点を室内温度と室内相対 湿度の頻度分布にして示す。期間 S は室内温度が低下し、室内相 対湿度が上昇する傾向が見られた。それぞれの期間における室内 温湿度の平均值を表 4 に示す。期間 S の方が期間 N に比べて気温 が $0.7{ }^{\circ} \mathrm{C}$ 低く、相対湿度が $5 \%$ 高かった。また、絶対湿度は期間 $\mathrm{S}$ 


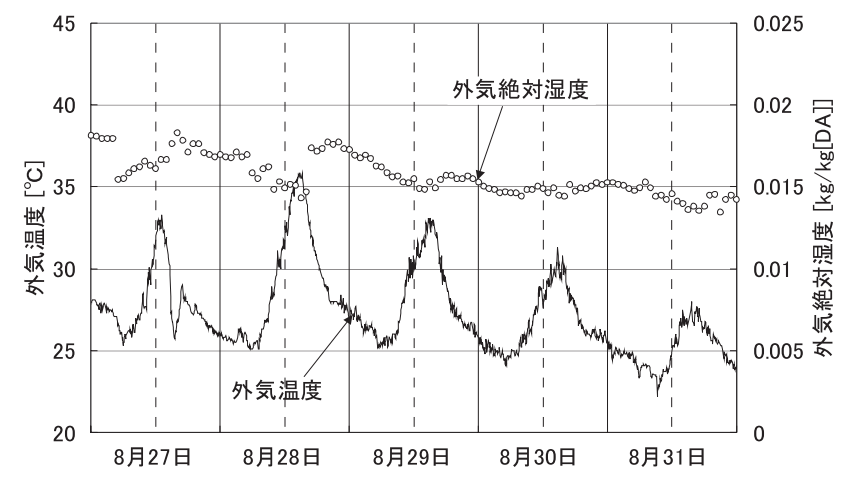

（a）期間 S（躯体蓄熱あり）

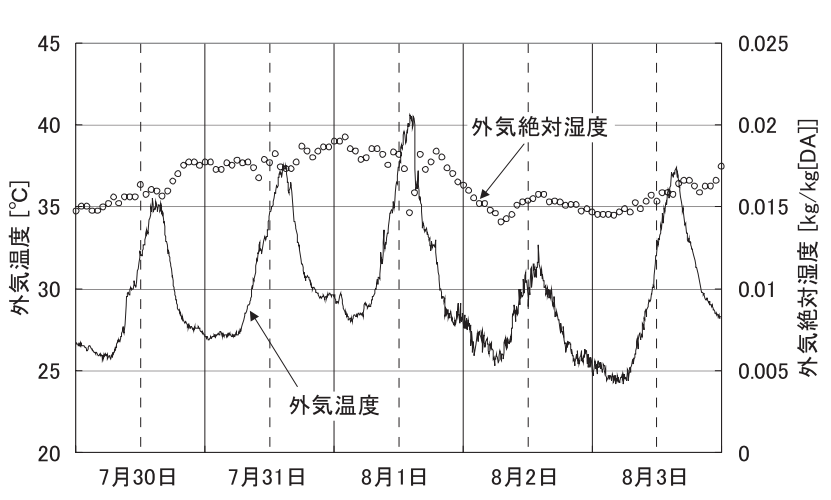

（b）期間 N（躯体蓄熱なし）

図2 外気温湿度の時間変動

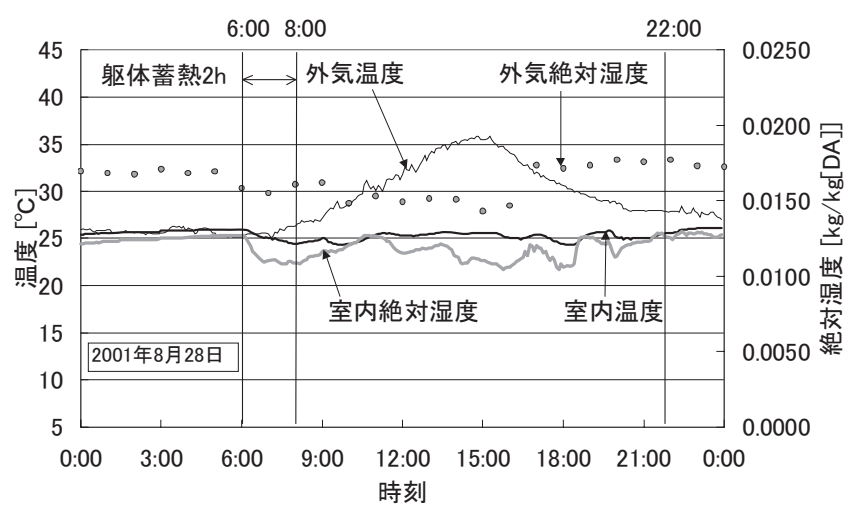

（a）期間 S（躯体蓄熱あり）

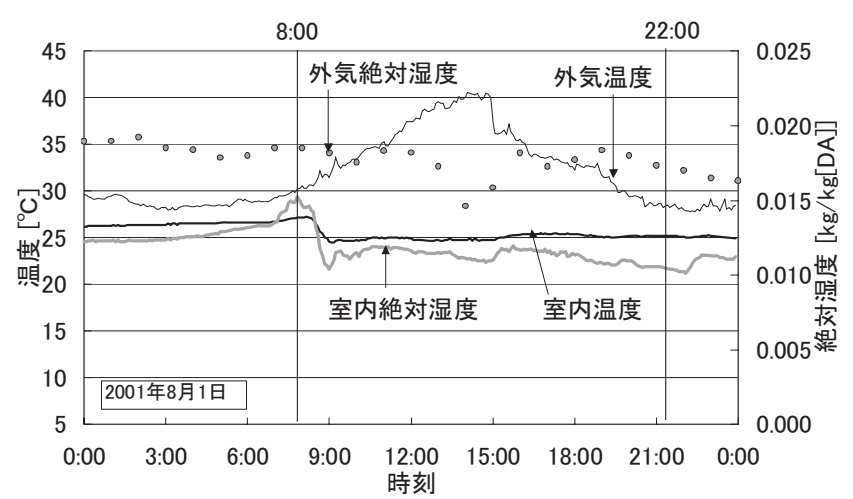

（b）期間 N（躯体蓄熱なし）

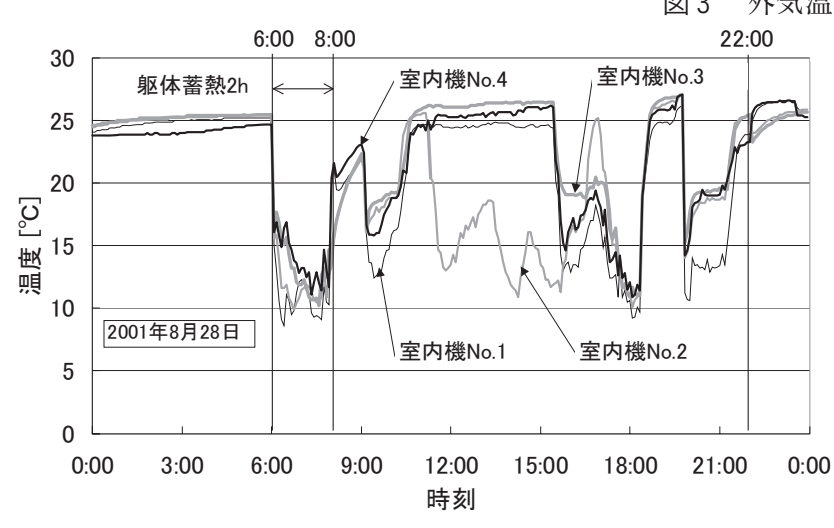

（a）期間 S (躯体蓄熱あり)

図 3 外気温湿度と室内温湿度変化

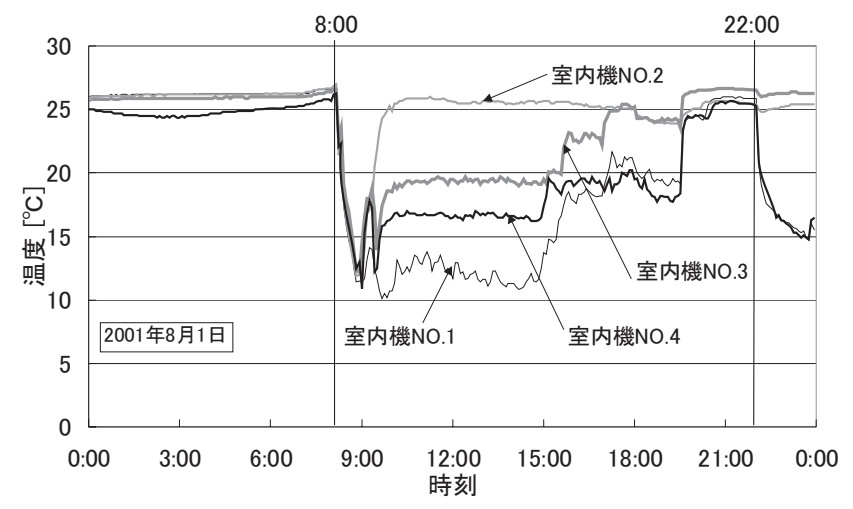

（b）期間 N（躯体蓄熱なし）

図 4 室内機吹出空気温度の変動

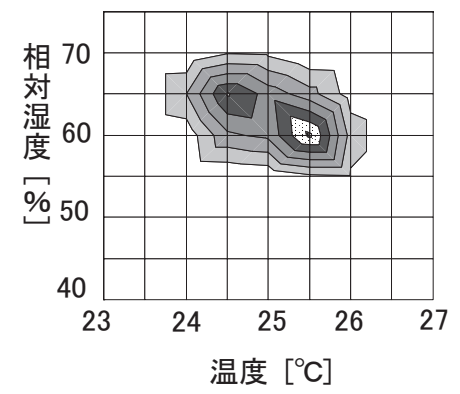

（a）期間 S（躯体蓄熱あり）

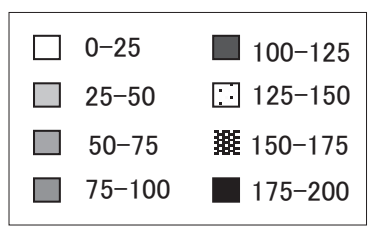

単位: 度数(1 回/5 分)

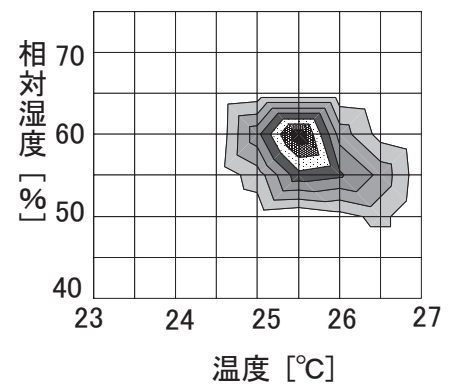

（b）期間 N（躯体蓄熱なし）

図 5 室内温湿度頻度分布の比較 
表 4 室内温湿度の比較

\begin{tabular}{|c|c|c|c|}
\hline & 温度 $\left[{ }^{\circ} \mathrm{C}\right]$ & 相対湿度[\%] & $\begin{array}{c}\text { 絶対湿度 } \\
{[\mathrm{kg} / \mathrm{kg}[\mathrm{DA}]}\end{array}$ \\
\hline $\begin{array}{c}\text { 期間S } \\
(8 / 27 \sim 8 / 31)\end{array}$ & 24.8 & 60 & 0.0117 \\
\hline $\begin{array}{c}\text { 期間N } \\
(7 / 30 \sim 8 / 3)\end{array}$ & 25.5 & 55 & 0.0112 \\
\hline
\end{tabular}

が $0.0005 \mathrm{~kg} / \mathrm{kg}[\mathrm{DA}]$ 高かった。相対湿度は室温の影響を受けるため 絶対湿度の違いを $26{ }^{\circ} \mathrm{C}$ に換算すると相対湿度で $2.4 \%$ の違いとな る。測定結果から躯体蓄熱を行うと室内湿度は上昇する傾向にあ ると推定されるが、躯体蓄熱を行わない場合との違いはそれほど 大きくなかった。

\section{3．躯体蓄熱がもたらす室内湿度環境の変化の解析}

実測結果から躯体蓄熱を行う場合には室内湿度が上昇する傾向 にあることが判った。しかし、それぞれの測定期間は外界条件が 異なり、内部発熱も全く同じではないと思われる。また、実測し た建物では躯体蓄熱時間は平日 2 時間であり、躯体蓄熱時間が室 内湿度上昇に与える影響は評価できなかった。以下では建物熱収 支と水分収支をモデル化したシミュレーションを用いて躯体蓄熱 の有無による室内湿度の変化を解析する。

3. 1 シミュレーション手法

躯体蓄熱のシミュレーションに求めら机る再現性として、以下 のものが上げられる4)。

(1) 梁を隔てた天井裏の温度分布を適切に再現できること

(2) 天井裏の上下温度分布を再現できること。

本論文では空間内を「ブロック」と呼ばれる小空間に分割して、 (1)ブロックと壁体間の対流熱伝達、(2)壁体表面における放射熱伝 達、(3)ブロック間の熱、水分と空気の移動、(4)壁体内の熱伝導を 考慮した温度と湿度の非定常計算を行い、各ブロックで熱量収 支、水分収支と風量収支を求める ${ }^{5)}$ 。壁体の蓄熱量と熱伝導によ る熱流は前進差分 (時間刻み 2 分) を用いた 1 次元非定常熱伝導計 算により評価し、接するブロックとの対流熱伝達を計算する。ブ ロック間の境界では熱移動係数 ${ }^{5)}$ による熱移動と空調気流による 空気の移動が生じるものとする。水平方向のブロック境界におけ る熱移動は境界を単純開口とみなして、温度差換気に相当する移 動熱量を計算する。また、ブロック間の水分移動量は空気移動に 伴う水分移動と共に、熱移動に相似な水分移動をルイスの関係に 基づき考慮する。

空調時の室内湿度変動は建物の熱・湿気同時移動と家具・什器 の潜熱容量の影響を受ける。室内における熱水分同時移動を考慮 した熱負荷計算は吉田 ${ }^{6)}$ 、谷本 ${ }^{7)}$ 等が行っている。坂本 ${ }^{8)}$ は事務所 において熱湿気同時移動と共に空調設備の冷却除湿コイルの特性 も考慮した計算では、室内の吸放湿性の効果よりも外気と内部発 湿の方が室内温湿度への影響が大きいために、室内の吸放湿性を 考慮すると空調停止時の湿度には影響があるが熱負荷に与える影 響は小さいと報告しており、空調時の室湿度に大きな違いが生じ ない結果を示している。本論文では室内における吸放湿に富んだ 材料が少なく、湿度に及ぼす影響が小さい場合を想定して、室内 の蓄湿要素は室容積に相当する空気のみを考慮する。但し、内装

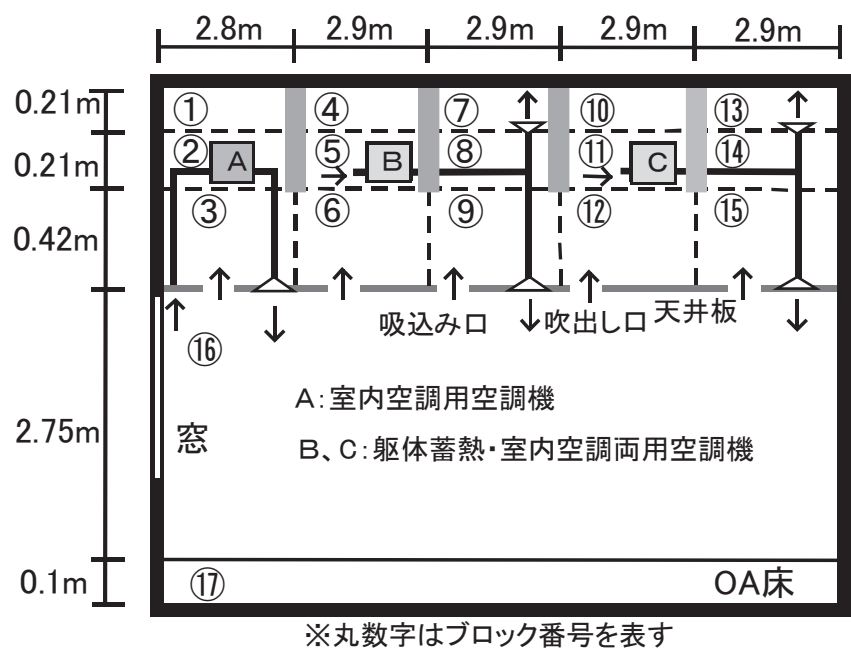

図 6 シミュレーション対象空間のモデル化 表 5 対流熱伝達率 $\left[\mathrm{W} / \mathrm{m}^{2}{ }^{\circ} \mathrm{C}\right]$

\begin{tabular}{ccc}
\hline 垂直面（室内壁面、梁、空面など） & 4.7 & \\
\hline 水平面 & 4.7 & 上向き熱流 \\
(室内床面や天井版上面・下面など) & 2.3 & 下向き熱流 \\
\hline 躯体蓄熱時に空気を吹き付ける天井裏スラブ下面 & \\
& 9.3 & \\
躯体蓄熱時間帯 & 4.7 & 上向き熱流 \\
その他の時間帯 & 2.3 & 下向き熱流 \\
&
\end{tabular}

や家具等の吸放湿材が多い場合には蓄熱時の放湿と空調時の吸湿 が室湿度に与える影響も大きくなると考えられるため，このよう な状態での躯体蓄熱により生じる室湿度変化は今後に取り扱うべ き課題とする。

\section{2 建物のモデル化}

シミュレーションの対象空間は $\mathrm{EN}$ ビルの基準階の西面の大梁に 囲まれる1 スパン（床面積: $92.2 \mathrm{~m}^{2} 、 6.4 \mathrm{~m} \times 14.4 \mathrm{~m}$ ) とする（図 1)。図 6 にモデル化された対象空間の断面図を示す。天井裏では、 躯体蓄熱時に空気を吹き付けるとスラブ近傍の空気温度が低下 し、吸込口に向かって温度が上昇することになる。躯体蓄熱時に は天井内に上下温度分布ができるため ${ }^{91}$ 、この温度分布を再現す るために天井裏は水平方向には 4 つの小梁で 5 分割、上下方向に は 3 分割を行い計 15 個のブロックに分ける。シミュレーションで はブロックの境界となる小梁、天井と $0 \mathrm{~A}$ 床は蓄熱量を持つ壁体と して扱い、天井裏の 15 個のブロックに室内として 1 ブロック、0A フロアとして 1 ブロックを加えて合計 17 個のブロックに分割して いる。ブロック内の温度、および各壁面毎の表面温度は一様とす る。建築仕様は表 2 に従いモデル化を行う。スラブは実際の建物 に用いている捨て型枠デッキプレートスラブと熱容量が等しい厚 さ $120 \mathrm{~mm}$ のコクリートスラブとする。天井裏外壁の断熱性能は 大梁の吹付岩綿 (厚み: $45 \mathrm{~mm}$ ) とする。シミュレーションに用いた 各種の対流熱伝達率を表 5 に示す。躯体蓄熱時には空気を吹き付 ける天井裏（7)及び (13)ブロック） スラブ下面全体の対流熱伝達率 が 9.3 W / $\mathrm{m}^{2}$ とする ${ }^{10)}$ 。天井裏と室内との熱移動は(1)天井板による 熱伝導、(2)空調時における室から天井裏へのレタン空気と (3)レタ ンスリットを介した空気の移動により行われるとする。天井板に 
開いているレタン用のスリットを介した空気の移動は参考文献 11 より天井裏容積を基準とした換気回数 1 回 $\left(49.2 \mathrm{~m}^{3} / \mathrm{h}\right)$ を与える。

計算対象空間の上階と下階の建築仕様と使用状態は対象空間と 同じとする。室内の蓄熱要素である家具や書類なども壁体とし て、参考文献 12 に従い、家具は鋼、書類は紙として床面積当たり の重量を想定する。

3.3 空調機のモデル化

断面内には空調機が 3 台設置されており、空調機 A は、図 6 中 (2)ブロックに設置され、室内とダクトで接続され空調時間帯のみ 運転する。空調機 B とC は(5)、(11)ブロックに設置され、躯体蓄熱 時の冷風はそれぞれ隣の (7)、13ブロックヘダクトで供給する。還 気は天井裏で(5)、(11)ブロックへ戻る。昼間はダンパを切り替えて ダクトで室内へ冷風を供給する。室内へ供給された冷風は天井板 スリットをとおり空調機 $\mathrm{B}$ 及び $\mathrm{C}$ へ戻る。吹出空気状態は乾きコ イルと湿りコイルを分離したコイルモデル13)を用いて計算を行 う。吹出空気相対湿度は参考文献 14 を参考にして $90 \%$ ～95\%の中

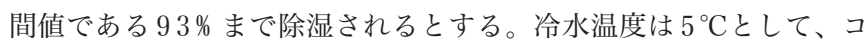
イル水量により必要に応じて吹出空気温度を制御する。

吹出風量は躯体蓄熱時は空調機 $\mathrm{B}$ 及び空調機 $\mathrm{C} の 2$ 台分の最大 風量である $2400 \mathrm{~m}^{3} / \mathrm{h}$ の定風量制御、空調時は空調機 $A 、 B 、 C$ の 3 台を用いた変風量制御とする。シミュレーションで用いる変風量 制御は風量制御範囲では吹出温度一定制御であるが、最小風量時 には室温を調整するために吹出温度設定值を上昇させる吹出温度 リセット制御を行う。外気量に相当する排気は吸込口が設置され ているブロックで行う。

本計算に用いる室空調時の空調機の制御は、室温と室温設定值 との偏差に応じてP I 制御で風量と吹出温度を変える方法を採用し ている。そのため、本ケースのように空調機の能力が熱負荷に対 して十分に余裕がある場合に 1 台の空調機が多くの熱負荷を処理 すると他の 2 台はほとんど熱負荷を処理しない傾向が生じ、制御 パラメー夕の違いによって各空調機処理熱量にばらつきが生じる ことが予備計算で分かった。そこで現象を単純化するために、躯 体蓄熱時には空調機 B と C を 1 台の空調機、室空調時には空調機 $\mathrm{A} 、 \mathrm{~B} 、 \mathrm{C}$ の 3 台の空調機を 1 台の空調機と取り扱い、運転される空 調機で吹出温度が同じになるようにする。吹出温度の計算には空 調機 A、B、C の合計と同等の性能を持つ一台の空調機を使用し、 冷却コイルの伝熱面積とコイル前面積は躯体蓄熱時、室空調時に かかわらず表 6 に示す值を用いる。

\section{4 計算条件}

\section{4.1 気象条件と計算期間}

気象条件は空気調和・衛生工学会の東京における標準年気象 デー夕を使用する。計算は 5 月から行い外気温湿度が高い 8 月を 解析対象とする。標準年気象データの 8 月における平均温度は $26.5^{\circ} \mathrm{C}$ 、絶対湿度 $0.0154 \mathrm{~kg} / \mathrm{kg}[\mathrm{DA}]$ である。

\section{4.2 室使用条件と空調機運転時間}

室の使用状態を再現するため、週末と祝日は室を使用せず、平 日のみに室が使用されるとする。内部発熱は照明発熱 $22 \mathrm{~W} / \mathrm{m}^{2}(9$ 時〜 22 時 : 100\%)、内部発熱 $22 \mathrm{~W} / \mathrm{m}^{2}$ (9 時〜 18 時：100\%、18 時〜 22 時: $33 \%$ )、人体発熱: 0.1 人/ $\mathrm{m}^{2}$ を元る(表 7 )。これら内部 発熱中で人体発熱のみが潜熱成分 $\left(64\right.$ W/ 人) ${ }^{14}$ )を含み、他は顕熱
表6 シミュレーションに用いたコイルの仕様

\begin{tabular}{|c|c|c|c|}
\hline & $\begin{array}{c}\text { コイル伝熱面積 } \\
{\left[\mathrm{m}^{2}\right]}\end{array}$ & $\begin{array}{c}\text { コイル前面積 } \\
{\left[\mathrm{m}^{2}\right]}\end{array}$ & $\begin{array}{c}\text { 最大水量 } \\
{[\mathrm{l} / \mathrm{min}]}\end{array}$ \\
\hline ケース0〜ケース3 & 57.9 & 0.4 & 82.3 \\
\hline ケース1C〜ケース1L & 同上 & 同上 & 同上 \\
\hline 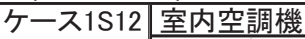 & 同上 & 同上 & 同上 \\
\hline ケース1S26 & 11.0 & 0.06 & 24.4 \\
\hline
\end{tabular}

表7室使用状況

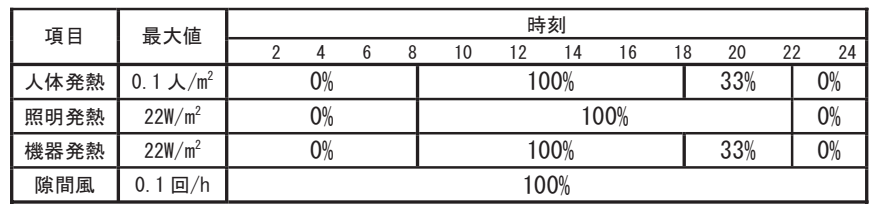

表8 空調機運転スケジュール

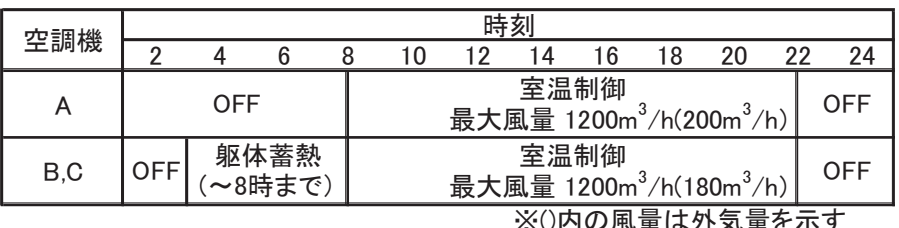

表 9 空調機運転スケジュール

\begin{tabular}{|l|c|c|}
\hline & 躯体蓄熱時間 & 室空調時間 \\
\hline ケース0 & なし & 平日8時〜22時 \\
\hline ケース1 & 平日6時〜8時 & 同上 \\
\hline ケース2 & 平日4時〜8時 & 同上 \\
\hline ケース3 & 平日2時〜8時 & 同上 \\
\hline
\end{tabular}

成分のみである。

\section{4. 3 空調機の制御と運転時間}

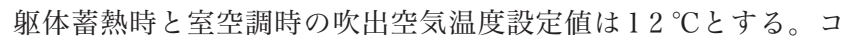
イル能力を超える場合には吹出温度が上昇するものとする。室空 調時には室（ブロック(16) 温度設定值を $26{ }^{\circ} \mathrm{C}$ する。躯体蓄熱は インテリア空調機のみで平日 6 時〜 8 時に行い、室空調はインテ リア空調機とペリメータ空調機共に 8 時〜 22 時に行う（表 8 ）。

3.5 躯体蓄熱時間による室内環境の比較

3. 5.1 シミュレーション条件

異なる躯体蓄熱時間により生じる室内温湿度の違いを比較する ため表 9 に示す 4 ケースのシミュレーションを行う。室内機の吹 出風量は躯体蓄熱時に空調機 B と空調機 C を用いて各々 $1200 \mathrm{~m}^{3} / \mathrm{h}$ $\left(\right.$ 計 $\left.2400 \mathrm{~m}^{3} / \mathrm{h}\right)$ 室使用時には、空調機 A、B、C のすべてを用いて各々

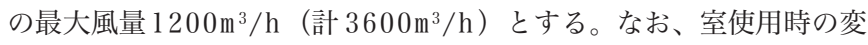
風量制御の最小風量は表 3 より最大風量の $68 \%$ （計 $2448 \mathrm{~m}^{3} / \mathrm{h} ）$ とす る。

\section{5.2 外界温湿度と室内温湿度}

各ケースで室使用時である平日 9 時〜 22 時の毎正時における室 内温湿度（ブロック(16)の温湿度）を用いて平均值を算出し、表 10 に示す。躯体蓄熱時間が長くなるにつれて室内湿度は上昇して ケース 0 とケース 3 では $4 \%$ の違いがあるが、室内温度はほとんど 違いがない。以下ではシミュレーションの代表日として標準年の 8 月 7 日 (月) を取り上げ解析を行う。図 7 には 8 月 5 日 (土) から 8 月 7 日 (月) にかけての外気温湿度の時間変化を示す。週末である 8 月 5 日 (土) と 8 月 6 日 (日) は気温が $30{ }^{\circ} \mathrm{C}$ を超える真夏日であるが 8 月 7 日は最高気温が $28.9^{\circ} \mathrm{C}$ それほど高くはなく、室使用時の 
表10 8 月の空調時間室内温湿度の比較

\begin{tabular}{|c|c|c|c|c|c|c|}
\hline & \multicolumn{3}{|c|}{ 室内温度 $\left[{ }^{\circ} \mathrm{C}\right]$} & \multicolumn{3}{|c|}{ 室内相対湿度 [\%] } \\
\hline & 最大值 & 最小値 & 平均值 & 最大值 & 最小値 & 平均値 \\
\hline ケース0 & 26.0 & 25.8 & 26.0 & 79 & 54 & 69 \\
\hline ケース1 & 26.0 & 25.8 & 26.0 & 80 & 54 & 71 \\
\hline ケース2 & 26.1 & 25.8 & 26.0 & 81 & 54 & 72 \\
\hline ケース3 & 26.1 & 25.9 & 26.0 & 82 & 54 & 73 \\
\hline
\end{tabular}

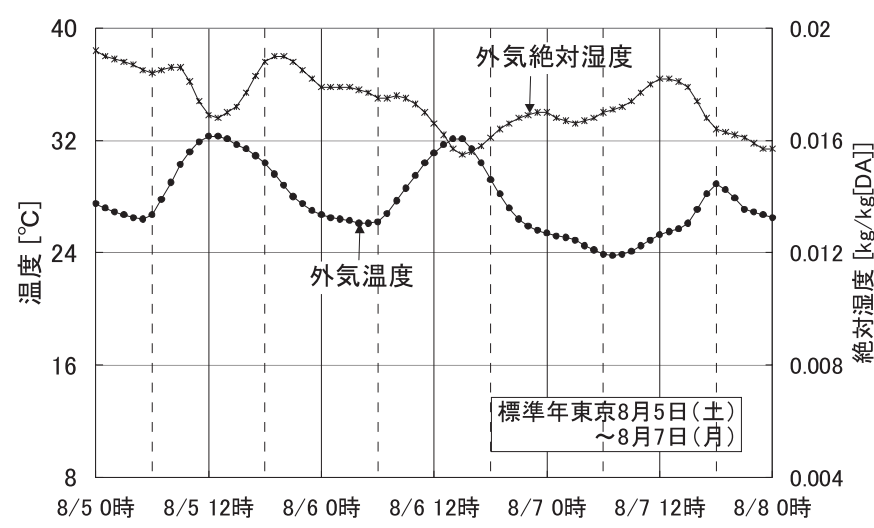

図7 標準年東京の 8 月 5 日〜 8 月 7 日の外気温湿度
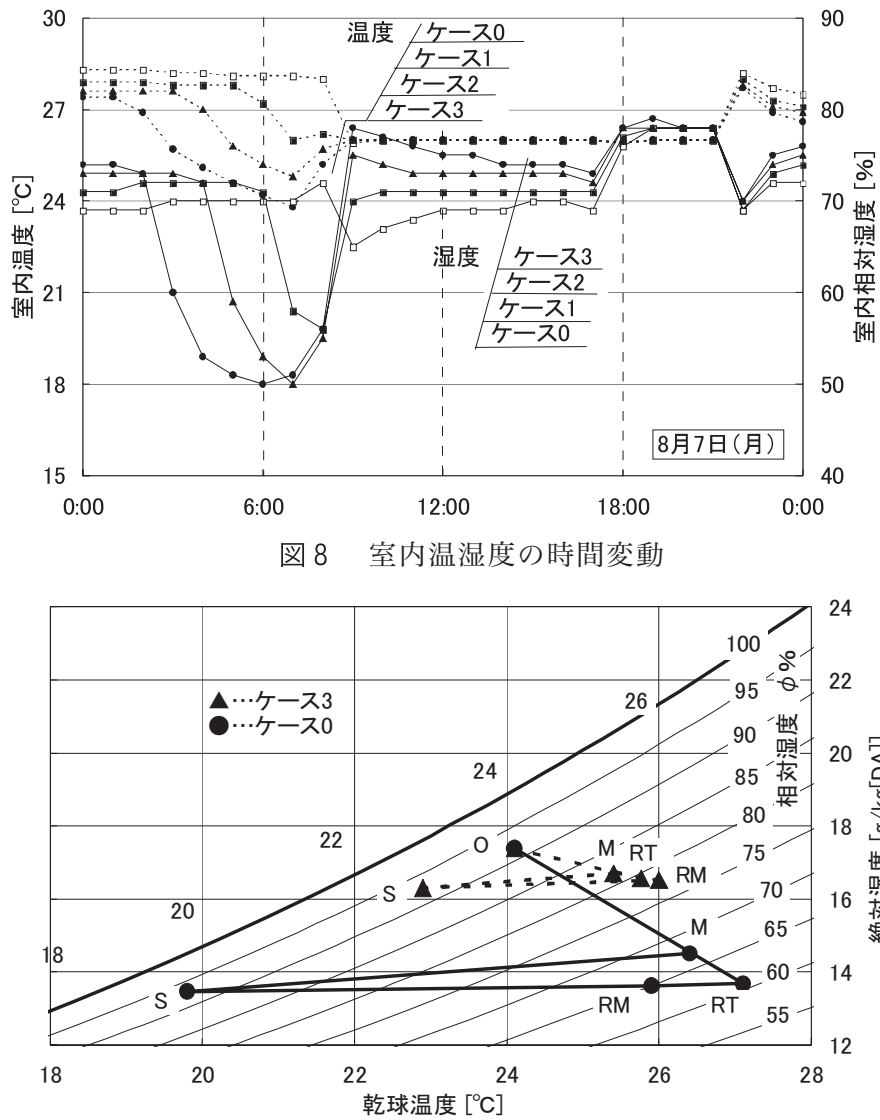

図 9 空気調和プロセスの状態変化 (8月 7 日（月） 9 時)
外気絶対湿度は $0.0161 \mathrm{~kg} / \mathrm{kg}[\mathrm{DA}] \sim 0.0182 \mathrm{~kg} / \mathrm{kg}$ [DA] である。この 外気湿度は室設定温度である $26{ }^{\circ} \mathrm{C}$ 相対湿度に換算すると $76 \%$ $86 \%$ に相当する。図 8 には 8 月 7 日の室内温湿度の変化を示す。室 使用時の空調機風量合計值は $2448 \mathrm{~m}^{3} / \mathrm{h}$ で変風量制御の最小值であ る。天井裏と室内の空気の移動を考慮しているため、躯体蓄熱時 に室温を室内湿度が低下している。室の使用を開始する 9 時に室

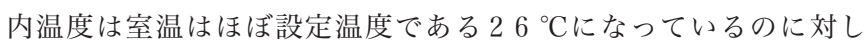
て、相対湿度は躯体蓄熱時間により異なり、躯体蓄熱を行わない ケース 0 では $65 \%$ 、6 時間の蓄熱を行うケース 3 では $78 \%$ と相対湿 度で $13 \%$ の違いがある。9 時以降の室内湿度の変化を見ると 17 時 迄ケース 0 は徐々に上昇しているが、ケース 1 はほとんど変わら ずケース 2 とケース 3 は徐々に低下している。1 8 時以降には室内 湿度に大きな違いは生じていない。本論文では室の蓄湿要素を考 慮しておらず実際の建物では建物や家具・什器が持つ吸放湿特性 の影響により湿度変動は小さくなると考えられる ${ }^{15)}$ が、代表日の 解析により躯体蓄熱時間の長短により室内湿度に大きな違いが生 じる時間があることが判る。

表 11 には、9 時におけるケース 0 〜ケース 3 の空調機における 空気調和プロセス温湿度変化を示す。点 0 は外気、点 R M は室、点 $\mathrm{RT}$ は天井裏の還気、点 M は空調機入口、点 S は空調機出口を示す。 各ケースの点 $\mathrm{S}$ を比較すると躯体蓄熱時間が長い程、吹出空気温 度が高く吹出空気湿度が上昇している。コイルモデルの特性上、 吹出空気 (点 S ) の相対湿度は $93 \%$ 迄しか低下しないので、吹出温 度の上昇に伴ない吹出空気絶対湿度は上昇するためである。ま た、各ケースの点 $\mathrm{R} T$ から点 $\mathrm{M}$ を経て点 $\mathrm{S}$ に至る変化を見ると点 $\mathrm{M}$ の絶対湿度は外気の影響を受けて点 $\mathrm{RT}$ よりも上昇している。シ ミュレーションにおける空気調和プロセスで絶対湿度を上げる要 因としては、(1)室内発湿（点 S から点RM）と(2)外気取り入れ（点 RT から点M) の 2 つがあるが、(2)の方が1)よりも大きくなっている。 図 9 にはケース 0 とケース 3 の空気調和プロセスを湿り空気線図 上に示す。室内発熱がいずれのケースも同じであるため、点 $\mathrm{S}$ か ら点 R M に至る直線の勾配は同じである。躯体蓄熱を行わないケー ス 0 では吹出空気 (点 $\mathrm{S}$ ) の温度が $19.8^{\circ} \mathrm{C}$ であるた点 $\mathrm{S}$ の絶対湿 度が $0.0135 \mathrm{~kg} / \mathrm{kg}$ [DA] と低く、室内温度 (点RM) が低くなっている。 一方、躯体蓄熱を平日に 6 時間行うケース 3 では吹出空気 (点 $\mathrm{S}$ ) の 温度が $22.9^{\circ} \mathrm{C}$ と高く絶対湿度が $0.0163 \mathrm{~kg} / \mathrm{kg}[\mathrm{DA}]$ と高い。そのた めに室内空気 (点 RM ) の絶対湿度が高くなる。

3.5.3 空調機処理熱量の比較

図 10 には、躯体蓄熱時間の長短差がもたらす空調機処理熱量の 8 月における積算值の違いを比較して示す。ここに示す熱量は、 空調機出口空気状態 (点 $\mathrm{S}$ ) と入口空気状態 (点 $\mathrm{M}$ ) から顕熱と潜熱 に分けて算出したもので、冷却が負值である。躯体蓄熱時間が長 くなれば、全日の処理熱量そのものは増加し、ケース 1 に比べて ケース 3 では $4.3 \%$ 増加している。一方で、室空調時の潜熱処理

表 11 空気調和プロセスの状態変化（8月 7 日（月） 9 時）

\begin{tabular}{|c|c|c|c|c|c|c|c|c|c|c|}
\hline & \multicolumn{2}{|c|}{ 吹出空気 (S) } & \multicolumn{2}{|c|}{ 入口空気 (M) } & \multicolumn{2}{|c|}{ 還気 (RT) } & \multicolumn{2}{|c|}{ 室(RM) } & \multicolumn{2}{|c|}{ 外気 (O) } \\
\hline & 温度 $\left[{ }^{\circ} \mathrm{C}\right]$ & $\begin{array}{c}\text { 絶対湿度 } \\
\text { [kg/kg[DA]] }\end{array}$ & 温度 $\left[{ }^{\circ} \mathrm{C}\right]$ & $\begin{array}{c}\text { 絶対湿度 } \\
{[\mathrm{kg} / \mathrm{kg}[\mathrm{DA}]]}\end{array}$ & 温度 $\left[{ }^{\circ} \mathrm{C}\right]$ & $\begin{array}{c}\text { 絶対湿度 } \\
{[\mathrm{kg} / \mathrm{kg}[\mathrm{DA}]]}\end{array}$ & 温度 $\left[{ }^{\circ} \mathrm{C}\right]$ & $\begin{array}{c}\text { 絶対湿度 } \\
{[\mathrm{kg} / \mathrm{kg}[\mathrm{DA}]]}\end{array}$ & 温度 $\left[{ }^{\circ} \mathrm{C}\right]$ & $\begin{array}{c}\text { 絶対湿度 } \\
{[\mathrm{kg} / \mathrm{kg}[\mathrm{DA}]]}\end{array}$ \\
\hline ケース0 & 19.8 & 0.0135 & 26.4 & 0.0145 & 27.1 & 0.0137 & 25.9 & 0.0137 & 24.1 & 0.0174 \\
\hline ケース1 & 21.1 & 0.0146 & 25.9 & 0.0155 & 26.5 & 0.0149 & 26.0 & 0.0149 & 24.1 & 0.0174 \\
\hline ケース2 & 22.0 & 0.0155 & 25.6 & 0.0162 & 26.1 & 0.0158 & 26.0 & 0.0158 & 24.1 & 0.0174 \\
\hline ケース3 & 22.9 & 0.0163 & 25.4 & 0.0167 & 25.8 & 0.0166 & 26.0 & 0.0166 & 24.1 & 0.0174 \\
\hline
\end{tabular}




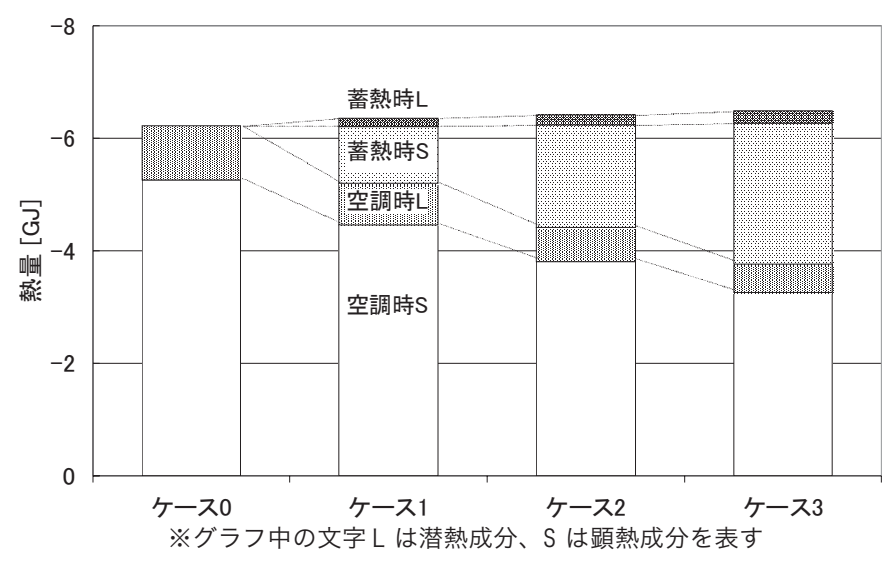

図 10 空調機処理熱量の比較

熱量は減少している。これは前項で述べた様に躯体蓄熱時間が長 くなると吹出温度が上昇して除湿ができなくなるためである。

\section{4. 室内湿度上昇の原因と対策}

\section{1 室内湿度上昇の原因についての考察}

前節で行ったシミュレーションにより、躯体蓄熱時間が長くな ると室使用時に吹出温度が上昇して空調機処理熱量潜熱成分が減 少するため、結果として室内湿度が上昇すると考えられる。躯体 蓄熱は熱源における蓄熱と異なり、室内温熱環境を制御する空調 機を用いて建築躯体に蓄熱を行う点に特徵がある。空気吹付方式 の躯体蓄熱は主として天井裏で上階床スラブと天井内の梁に蓄熱 を行なうが、本論文のシミュレーション結果にも現れている様に 躯体蓄熱時間に室温が低下するため、室内に空調機処理熱量の 30 \%程度が移動すると言われている ${ }^{16)}$ 。シミュレーションでは建物 や家具・什器の吸放湿量は小さいとして、その特性を考慮してい ない。そのため、室内へ移動した熱量は家具や間仕切壁等の温度 変化として蓄熱され、室使用時に室顕熱負荷の削減にのみ寄与し 室潜熱負荷の削減は行なわれない。一方、空調システムの吹出温 度は設定室温との偏差に応じて制御される室顕熱負荷に応じて吹 出温度が決まる。従って躯体蓄熱を行なうと吹出温度が上昇して 除湿が十分にできなくなり、室内湿度が上昇することになる。ま た、シミュレーションで用いている変風量制御では風量が制御範 囲にあれば吹出温度は一定だが、最小風量時の吹出温度リセット 制御により吹出温度が上昇する場合に導入外気の除湿がしづら く、室湿度の上昇につながる。

\section{2 対策と課題}

前章の解析により、躯体蓄熱時の湿度上昇の原因は室使用時の 顕熱負荷減少に伴なう吹出温度の上昇であることが明らかになっ た。ASHRAE Standard 55-200417)では室内絶対湿度条件の推奨值と して $0.012 \mathrm{~kg} / \mathrm{kg}[\mathrm{DA}]$ としている。気温 $26^{\circ} \mathrm{C} て ゙ は$ 相対湿度 $57 \%$ に相 当するため、室内の熱的快適性を維持するには湿度の調整が必要 になると考えられる。また、躯体蓄熱時間を長くすると「建築物 における衛生的環境の確保に関する法律」の相対湿度の上限であ る $70 \%$ 超える可能性があるため対策が必要だと考えられる。

空調設備を用いた対策としては以下の 3 つが考えられる。
（1）空気調和プロセスで除湿再熱処理を行なう

この方式はクリーンルーム等の恒温空間に用いられる。運転実 績もあり確実に室内湿度の調整を行なうことができる。

（2）変風量方式の最小風量設定を下げる

代表日のシミュレーション結果では一日を通して変風量方式の 最小風量設定值となっており、吹出温度はリセット制御により 設定值から上昇していた。最小風量設定值を小さくすれば、吹 出温度が上昇する頻度は減少すると思われる。

(3) 外気を独立して処理する

代表日のシミュレーション結果では外気を混合するために上昇 する空調機入口空気の水分を除去できなくなる場合が見られた。 従って外調機を用いて外気の除湿処理を確実に行なえば、室内 湿度はそれ程上昇しないと思われる。

上述の（1）は実績が多く、効果も確認されている。本論文では (2) と (3) の効果と課題を検討する。

\section{2. 1 変風量方式の最小風量設定を下げる場合の効果}

吹出風量の違いによる室内湿度の変化を調べるため平日に 2 時 間躯体蓄熱を行うケース 1 (最小風量: $2448 \mathrm{~m}^{3} / \mathrm{h}$ ) と、風量一定（風 量 $3600 \mathrm{~m}^{3} / \mathrm{h}$ ：ケース $1 \mathrm{C} ）$ とした場合、最小風量 $1440 \mathrm{~m}^{3} / \mathrm{h}$ （最大風 量の $40 \%$ ：ケース $1 \mathrm{~L} ）$ とした場合の 8 月における室内湿度の平均 值、最大值及び最小值を表 12 に示す。外気は定風量を空調機レ夕

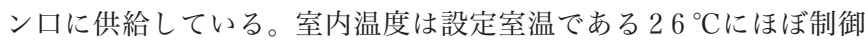
されているが、室内湿度はケース $1 \mathrm{C}$ で平均 $74 \%$ 、ケース $1 \mathrm{~L}$ で平 均 $62 \%$ と $12 \%$ の違いがある。 8 月 7 日におけるケース 1C とケース $1 \mathrm{~L}$ 及びケース 1 の室内温湿度を比較して図 11 に示す。室内温度 は室空調を開始する 8 時以外はほとんど同じである。 8 時の温度 が異なるのは空調開始時の風量と吹出温度が各ケースで異なるた めである。一方、室内湿度は 0 時から 6 時迄の非空調時間と 6 時 から 8 時の蓄熱時間はほとんど変わらないが、室使用時間は大き く異なる。最小風量設定值を下げたケース $1 \mathrm{~L}$ では 17 時迄は $60 \%$ を下回っている一方で、ケース $1 \mathrm{C} て ゙ は 80 \%$ 近い。但し、ケース $1 \mathrm{~L}$ でも内部発熱が減少する 18 時以降は湿度が徐々に上昇し 19 時 以降は $70 \%$ を越えている。従って内部発熱が小さくなると最小風 量設定值を小さくしても、室内湿度は上昇する。

図 12 には、ケース 1 、ケース $1 \mathrm{~L}$ 、ケース $1 \mathrm{C}$ の空調機処理熱量 の 8 月積算值を示す。いずれのケースも躯体蓄熱は平日に 2 時間 行なっているため、躯体蓄熱時の処理熱量はほとんど変わらな い。一方で室使用時には最小風量設定值を下げる程、潜熱負荷が 増えていることが判る。

\section{2. 2 外気を独立して処理する場合の効果}

外調機を設けて外気を独立して処理し、直接に室に給気する場 合の 8 月空調時間における平均值を表 13 に示す。外調機は定風量 $560 \mathrm{~m}^{3} / \mathrm{h}$ 、空調機の最大風量は $3040 \mathrm{~m}^{3} / \mathrm{h}$ として室への空調機給気風 量最大值は変えていない。外調機は吹出温度制御を行い、吹出温

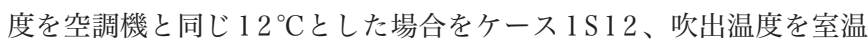
設定值と同じ $26^{\circ} \mathrm{C}$ した場合をケース 1S 26 と示している。表よ りケース 1S 12 は湿度が $52 \%$ ～ 7 \%の範囲となっており空調時間 帯の湿度に大きな変化はないが、ケース 1S 26 では $54 \%$ ～ $81 \%$ と 変化に幅があることがわかる。図 13 には 8 月 7 日の室内温湿度時 
表 12 最小風量変更時の空調時室内温湿度 (標準年東京 8 月)

\begin{tabular}{|l|r|r|r|r|r|r|}
\hline & \multicolumn{3}{|c|}{ 室内温度 $\left[{ }^{\circ} \mathrm{C}\right]$} & \multicolumn{3}{|c|}{ 室内相対湿度 [\%] } \\
\cline { 2 - 7 } & 最大值 & 最值 & 平均值 & 最大值 & 最小值 & 平均値 \\
\hline ケース1C & 26.0 & 25.9 & 26.0 & 84 & 54 & 74 \\
\hline ケース1 & 26.0 & 25.8 & 26.0 & 80 & 54 & 71 \\
\hline ケース1L & 26.1 & 25.7 & 26.0 & 73 & 54 & 62 \\
\hline
\end{tabular}

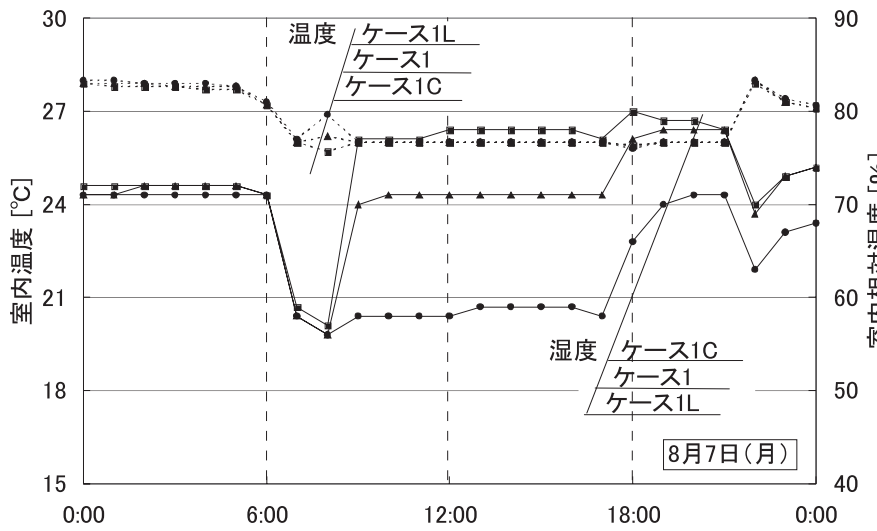

図 11 最小風量変更時の室内温湿度時間変動

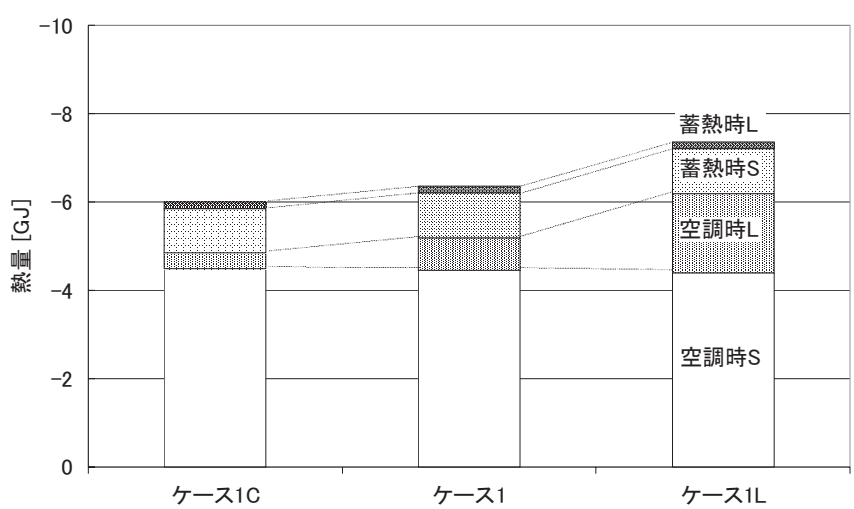

※グラフ中の文字 L は潜熱成分、S は顕熱成分を表す

図 12 最小風量変更時の空調機処理熱量の比較

間変化を示す。 0 時から 6 時にはいずれのケースでも温湿度の大 きな違いはない。外気を取り入れて室空調を始める 8 時以降は室 温に大きな違いはないが、ケース 1S 12 の湿度はケース 1 とケース 1S 26 に較べて低くなっており、外調機の吹出温度設定值により室 内湿度差に大きな差も生じている。1 8 時以降は内部発熱が減少す るため、ケース 1 とケース 1 S 26 は室内湿度が上昇している。 方、ケース $1 \mathrm{~S} 12$ では発湿源である在室者が減少した後も除湿され た外気が室に供給され続けるため、室内湿度が低下している。

図 14 には 8 月の空調機処理熱量積算值を示す。躯体蓄熱時の処 理熱量はいずれのケースも変わらない。外調機の処理熱量はケー ス 1S 26 では潜熱成分はほとんどなく、ほぼ顕熱成分のみである。 室内空調機は風量が減少したため吹出温度が低下し潜熱成分が増 加している一方で、外調機に等しい量の顕熱成分が減少してい る。ケース $1 \mathrm{~S} 12$ では外調機の処理熱量が顕熱潜熱ともに大幅に増 加し、室内空調機の処理熱量がケース 1 の半分となっている。す べての空調機を合計した処理熱量はケース 1 よりも $30 \%$ 増加して いる。

図 15 には、標準年東京 8 月の外気絶対湿度の累積比率と外調機
表 13 外気処理独立時の空調時室内温湿度 (標準年東京 8 月)

\begin{tabular}{|l|r|r|r|r|r|r|}
\hline & \multicolumn{3}{|c|}{ 室内温度 $\left[{ }^{\circ} \mathrm{C}\right]$} & \multicolumn{3}{|c|}{ 室内相対湿度 [\%] } \\
\cline { 2 - 7 } & 最大值 & 最值 & 平均值 & 最大值 & 最小值 & 平均値 \\
\hline ケース1 & 26.0 & 25.8 & 26.0 & 80 & 54 & 71 \\
\hline ケース1S26 & 26.1 & 25.8 & 26.0 & 81 & 54 & 70 \\
\hline ケース1S12 & 26.0 & 25.8 & 26.0 & 57 & 52 & 56 \\
\hline
\end{tabular}

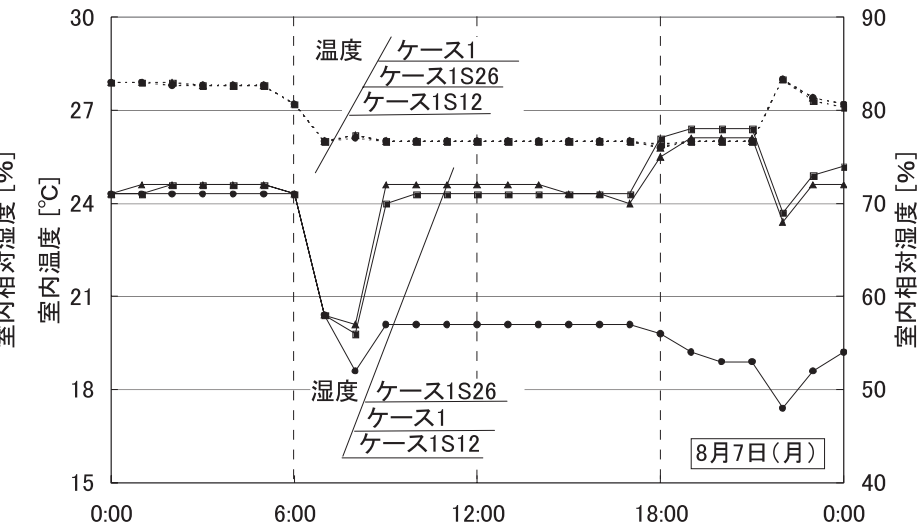

図 13 外気処理独立時の室内温湿度時間変動

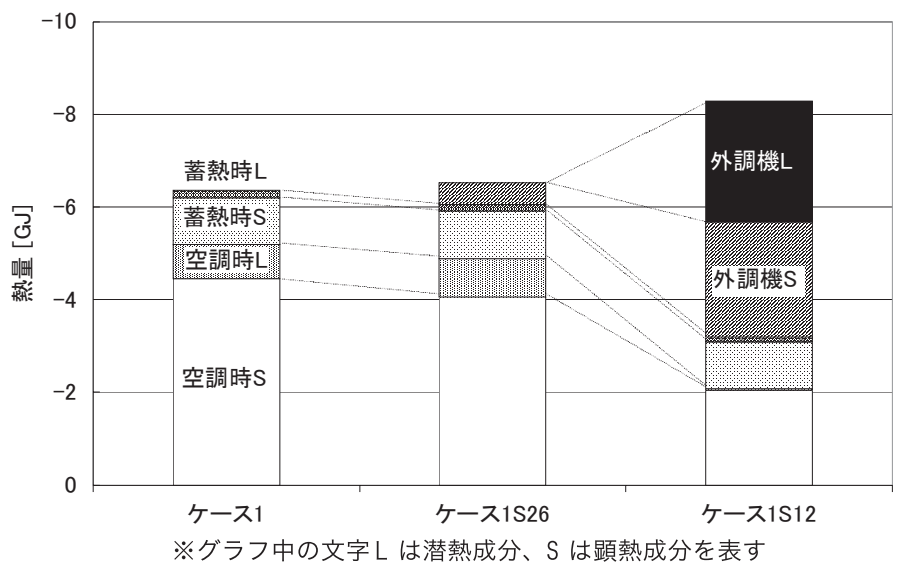

図 14 外気処理独立時の空調機処理熱量の比較

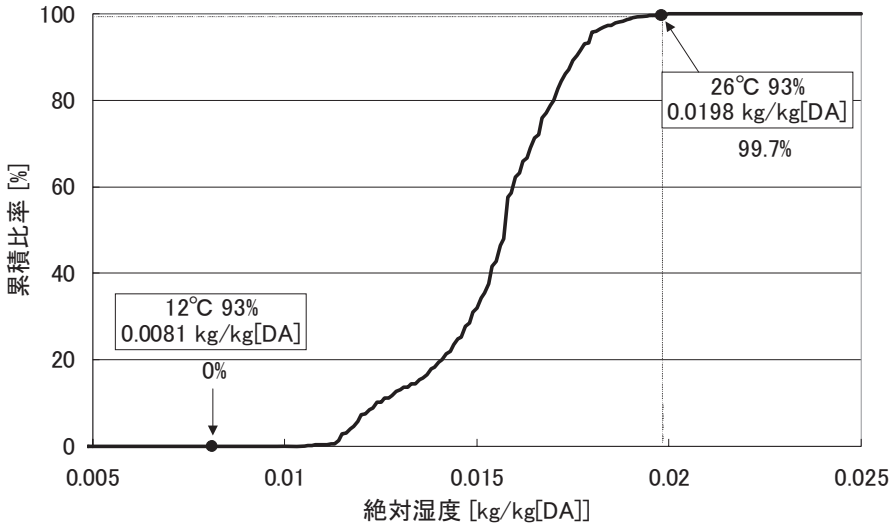

図 15 外気絶対湿度の累積比率 (標準年東京 8 月)

吹出空気湿度の関係を示す。シミュレーションに用いたコイルモ デルでは、コイル出口空気を $93 \%$ 迄除湿するため、外気がコイル 出口空気湿度を上回ると除湿されることになる。図より、ケース $1 \mathrm{~S} 12$ では 8 月は常に除湿されるのに対してケース1S26 では時間割 合にして $0.3 \%$ しか除湿が行なわれない事が判る。従ってケース 
1S 12 では室内湿度範囲が狭く、ケース 1S 26 では外気湿度の影響 を受けて室内湿度範囲が広いと考えられる。

以上の検討より外気を独立して適切な処理を行なえば、躯体蓄 熱による室使用時の湿度上昇を防ぐことができるが、空調機処理 熱量は増加することがわかった。但し、外調機を設置しても制御 が不適切な場合には図 14 のケース1S26 に見られる様に外気が除 湿されないままで室内に供給され、室内の湿度調整ができなくな る。そのため、吹出温度設定值などの外調機制御パラメー夕を決 めるには外気の除湿を考慮することが重要だと考える。

5. まとめ

躯体蓄熱による室内湿度の上昇を把握するため建物で実測を 行った。また、シミュレーションを用いて湿度上昇と原因を定量 的に解析し、湿度上昇への対応策と効果を示した。以下に本論文 で得た成果をまとめる。

(1) 平日に 2 時間躯体蓄熱を行う東京に立地する建物で実測を行 い、躯体蓄熱を行うと室内湿度が上昇する傾向にあることを確認 した。

（2）建物や家具・什器が湿度に与える影響が小さい場合、躯体蓄 熱を行うと室内湿度が上昇する傾向にあることをシミュレーショ ンにより示した。湿度の上昇は蓄熱時間が長いほど大きくなり、 標準年 8 月 7 日の比較では平日に 6 時間躯体蓄熱を行うと躯体蓄 熱を行わない場合に比べて 9 時の相対湿度が $13 \%$ 高くなっていた。 また、躯体蓄熱による室内湿度の上昇は午前中に大きかった。

( 3 ) シミュレーションにおける室内湿度の上昇は空調機吹出空気 温度が上昇するため、給気が十分に除湿されずに生じる事を示し た。吹出温度の上昇は蓄熱時間に発生する室内の蓄熱により空調 時間の顕熱負荷が減少するために生じると考えられる。

（４）躯体蓄熱による室内湿度の上昇を防ぐために、(1)変風量制御 方式の最小風量を小さくする方法と、(2)外気を独立で処理する方 法の効果を示した。いずれの方法も効果はあるが、変風量制御の 最小風量を小さくすると内部発熱が小さくなる時間帯には室内湿 度が上昇した。また、外気を独立に処理すると吹出温度などの制 御パラメー夕の設定值が不適切だと外気が除湿されずに室内湿度 が上昇する点に注意が必要だと考えられる。

\section{謝辞}

本論文をまとめるに際しては、京都大学工学研究科都市環境工 学専攻吉田治典教授並びに王福林助教より貴重なご助言を頂い た。また、博士後期課程の山口弘雅氏、潘嵪氏からは有益なご意 見を頂いた。記して感謝の意を表します。

\section{参考文献}

1) 石野久彌、郡公子、永田明寬、湯原慶子、島田宣広、山田祐三、金政秀、「身 体蓄熱空調を適用した建物の熱環境・熱負荷の性能評価 第 2 報 室内熱 環境の特性」空気調和・衛生工学会学術講演会講演論文集、2003.9

2) 香川治美、龍有二、相楽典泰、宋城基、村上洋、馬場敬之、香月憲昭「床吹 出型躯体蓄熱空調システムを採用した事務所ビルの性能評価 その 2 温熱 環境評価」日本建築学会大会学術講演梗概集 環境工学 II、2004.8
3) 文部科学省 国立天文台編 理科年表 第 77 冊 丸善株式会社 平成 16 年

4) Miura, K., "The Analysis of a Thermal Storage System Utilizing Building Mass in a Cold Region” ,Building Simulation 2007, Beijing, 2007. 9

5 ) 戸河里敏、荒井良延、三浦克弘「大空間における上下温度分布の予測モデル 大空間の空調・熱環境計画手法の研究 その 1 」、日本建築学会計画系論 文報告集、第 427 号、1991.9

6) 吉田治典「室の吸放湿と室内温湿度変動」日本建築学会環境工学委員会熱環 境運営委員会第 21 回熱シンポジウム「建物と湿気 - 現象の解析と設計」、 1991.8

7 ) 谷本潤、木村建一「室内仕上げ材の調湿効果の定量化と実験に基づく室内熱 負荷のシミュレーション」日本建築学会計画系論文報告集、第 421 号、1991.3

8 ) 坂本雄三、松尾陽、永田明寛、金桓龍「潜熱負荷と湿度変動に及ぼす室内備 品類の吸放湿性の影響に関する研究 その 2 シミュレーションによる吸放 湿性の影響に関する検討」日本建築学会学術講演梗既集、環境工学 I I 、 1996.9

9 ) 大和田淳、葛岡典雄、三浦克弘、「実物建物での性能実測とシミュレーショ ンとの比較、躯体蓄熱空調システムの設計法に関する研究 その $7 」$ 日本 建築学会大会学術講演梗概集、環境工学 II 、2004.8

$10)$ 相楽典泰、三浦克弘「躯体蓄熱と氷蓄熱ビル用マルチを組み合わせた 4 つ の空調方式におけるエネルギー性能比較」、日本建築学会環境系論文集 第 600 号、2006. 2

11 ) 石野久彌、郡公子、永田明寛、佐藤豊、向後亮、島田宣広、山田祐三、金 政秀、「躯体蓄熱空調を適用した建物の熱環境・熱負荷の性能評価 第 4 報 天井板の漏気量特性と天井空間の熱収支」、空気調和・衛生工学会学術講 演会講演論文集、2003.9

$12)$ 石野久爾、郡公子、「事務所建築における家具類の熱的影響に関する実測・ 実験研究」、日本建築学会計画系論文集 第 372 号、1987.2

13）社団法人建築設備技術者協会 空調システム標準シミュレーションプログ ラムHASP/ACSS/8502 プログラム解説書 昭和 61 年

14 ) 井上宇市編 空気調和ハンドブック 改訂 4 版 丸善株式会社

$15)$ 三浦克弘、相楽典泰、鈴木孝佳、坪田祐二「氷蓄熱用低温冷風空調システ ムの開発（その 7 ）低温冷風空調システムにおける空調立ち上がり時の温 湿度変動特性」空気調和・衛生工学会学術講演会論文集、1998.8

16) 松尾陽監修、(財) ヒートポンプ・蓄熱センター躯体蓄熱研究会出版W G「躯 体蓄熱」、オーム社、平成 19 年 3 月

17) ANSI/ASHRAE Standard 55-2004 “Thermal Environmental Condition for Human 0ccupancy" , American Society of Heating, Refrigerating and Air-Conditioning Enginees, Inc., 2004

(2008年 4 月 9 日原稿受理, 2008年 8 月29日採用決定) 